\title{
Gliadin Degradation Ability of Artisanal Lactic Acid Bacteria, The Potential Probiotics from Dairy Products
}

\author{
Gokcen Komen, Ayse Handan Baysal and Sebnem Harsa*
}

Department of Food Engineering, Izmir Institute of Technology, Faculty of Engineering, 35430, Urla, Izmir, Turkey

\begin{abstract}
Selected Lactobacillus spp. with high protease and acid producing capacity was explored for effective gliadin degradation in wheat sourdough environment. The total titratable acidity (TTA), $\mathrm{pH}$ and lactic acid bacteria (LAB) counts were evaluated. At the end of fermentation, the acidity and $\mathrm{pH}$ of the sourdough samples reached to 13.49-17.34 and 3.84-3.52 range, respectively. LAB population was enumerated as $10^{7}-10^{9}$ colony forming unit (CFU)/g dough. Gliadin profiles were examined qualitatively using sodium dodecyl sulfate-polyacrylamide gel electrophoresis (SDS-PAGE), twodimensional electrophoresis (2-DE) and reverse phase-high performance liquid chromatography (RP-HPLC) techniques. Especially RP-HPLC could be considered as a sensitive technique and is useful to determine the biochemical changes in gliadin fragmentation throughout sourdough fermentation process. LAB inoculated sourdoughs and chemically acidified sourdoughs generally represent similar gliadin degradation patterns. Although the total removal of gliadin toxicity could not be achieved in all dough formulations, it may be beneficial to use LAB to improve the dough and bread quality through the exploration of its bioconversion by-products.
\end{abstract}

Keywords: Gliadin, sourdough, lactic acid bacteria, probiotic, celiac.

\section{INTRODUCTION}

The wheat storage protein, gluten, is composed of gliadin and glutenin fractions which have amino acid sequences rich in proline and glutamine residues [1]. However, ingestion of gluten causes celiac, gluten sensitive enteropathy, in genetically susceptible individuals. High proline and glutamine content makes gluten proteins resistant to gastrointestinal digestion enzymes which lack postproline cleaving activity $[2,3]$. After reaching small intestine, immune response is activated and mucosa structure is damaged. The damage causes malabsorption and several related health problems such as malabsorption, abdominal pain and bloating, chronic diarrhea, growth failure, iron deficiency anemia, nonspecific arthritis, depression and low bone mineral density [4]. Celiac has an incidence of 1 of 100-550 people in European population [5] and gluten-free diet has a key and unique role for the treatment. At this point, the variety, availability, quality and affordability of gluten-free products on the market are of great importance. Therefore, substantial efforts are exerted on the development of new products. Furthermore, gluten contamination of naturally glutenfree foods and residual gluten in gluten-free ingredients exhibit a serious problem.

Sourdough is a fermented semi-product that is the mixture of basically wheat flour and water. It contains

*Address correspondence to this author at the Department of Food Engineering, Izmir Institute of Technology, Faculty of Engineering, 35430, Urla, Izmir, Turkey; Tel: +9 (0) 232750 6291; Fax: +9 (0) 232 7506196;

E-mail: sebnemharsa@iyte.edu.tr
LAB, mostly Lactobacillus strains, and yeasts. As sourdough fermentation progresses, several microbial and enzymatic bioconversions occur in carbohydrates, lipids and proteins [6]. The protein degradation is mediated by both microbial metabolism and cereal enzymes. As a result of microbial growth, acidity decreases, which makes the proteins more susceptable to degradation. The acidification leads to activation of endogenous proteolytic enzymes of wheat flour, such as aspartic and serine proteinases which have acidic $\mathrm{pH}$ optima [7-9]. Together with these wheat enzymes, proteolytic activities of LAB probably result in degradation of gluten proteins, hence amino acid concentration increases. Proteolysis during sourdough fermentation with additional LAB strains has been investigated by several researchers [10-15]. These results have revealed that sourdough fermentation is probably a promising approach to detoxify residual gluten. Additionally, it has been reported that sourdough fermentation enhances the texture, flavor and shelf-life of the final product and also it has a significant effect on nutritional value through a serial of bioconversions [16-19]. Microbial exopolysaccharides are long chain polysaccharides, which consist of branched and repeated units of sugar and sugar derivatives. They have positive effects on dough rheology and bread quality and also they have prebiotic properties [20-24].

LAB isolated from dairy products have been widely investigated for their proteolytic activity $[25,26]$. LAB isolates from dairy products have already been used for bread production through sourdough process and 
desirable effects on bread quality were obtained [2729]. Also, a commercial probiotic preparation was used in sourdough formulation [13]. Since the strains showed proteolytic activity, this preparation was suggested to use for the removal of gluten traces.

The scope of this study is to explore the effectiveness of potential probiotic $L A B$, isolated from artisanal dairy products in Turkey, for their gliadin degradation capabilities. Lactobacillus casei D4 and Lb. delbrueckii ssp. bulgaricus TY30, were selected for their high proteolytic activity and exopolysaccharide content, respectively $[30,31]$. Contributions from the enzymatic system of $L A B$ on the hydrolysis of gluten has been primarily important, whereas the exopolysaccharide investigations are underway since these metabolites have importance on improving bread structure.

\section{MATERIALS AND METHODS}

\subsection{Microorganisms and Media}

In sourdough formulations, three different LAB strains were used. 1) Lb. acidophilus NRRL-B 1910 was selected as a reference strain and obtained from Agricultural Research Service Culture Collection (NRRL, U.S.). 2) Lb. casei D4 and 3) Lb. delbrueckii ssp. bulgaricus TY30 were isolated previously from a traditional cheese (Comlek peyniri) and yoghurt (Toros yogurdu), respectively in previous studies which were conducted at Food Engineering Department of IZTECH $[30,32]$. A hundred $\mu \mathrm{L}$ of each $L A B$ were taken from frozen glycerol stocks and inoculated to $5 \mathrm{~mL}$ of de Man, Rogosa and Sharpes (MRS) Broth [52.2 g MRS broth (Merck 10661)/L deionised water]. The broths containing Lb. acidophilus NRRL-B 1910 and Lb. casei
D4 were incubated at $37^{\circ} \mathrm{C}$ for 24 hours (h), and $L b$. delbrueckii ssp. bulgaricus TY30 was incubated at $42^{\circ} \mathrm{C}$ for $24 \mathrm{~h}$. Subculture was done for each $L A B$ and overnight incubated Lactobacillus cells were used for sourdough fermentation.

\subsection{Wheat Flour Analyses}

Wheat flour was supplied from a local market. Protein content of wheat flour was analyzed according to Kjeldahl method with some modifications in the amounts of chemical solutions [33]. Moisture and ash contents of wheat flour were determined according to ICC Standard No. 110/1 [34] and 104/1 [35], respectively.

\subsection{Preparation of Sourdough}

The $L A B$ cells of each strain were harvested via centrifugation at $5000 \mathrm{r}$. $\mathrm{min}^{-1}$ for $15 \mathrm{~min}$ at $4^{\circ} \mathrm{C}$. After washing with phosphate buffered saline (PBS) $[\mathrm{NaCl}(8$ $\mathrm{g} / \mathrm{L}), \mathrm{KCl}(0.2 \mathrm{~g} / \mathrm{L}), \mathrm{Na}_{2} \mathrm{HPO}_{4}(1.44 \mathrm{~g}), \mathrm{KH}_{2} \mathrm{PO}_{4}(0.24$ $\mathrm{g} / \mathrm{L}), \mathrm{pH} 7.4$ ], LAB cells were suspended in water and the cell concentrations were adjusted to $2 \times 10^{8} \mathrm{CFU} / \mathrm{mL}$ suspension. Wheat flour (200 grams) was mixed manually with tap water $(100 \mathrm{~mL})$ that contains $2 \times 10^{8}$ CFU of related LAB suspension to produce $300 \mathrm{~g}$ of dough (Table 1) [10]. Each Lactobacillus strain had the final concentration of $2 \times 10^{7} \mathrm{CFU} / \mathrm{g}$ dough. The sample codes with the name of inoculated strain(s) were as $L b$. acidophilus NRRL-B 1910 (LA), Lb. casei D4 (LC), Lb. delbrueckii ssp. bulgaricus TY30 (LD), Lb. casei D4 and $L b$. delbrueckii ssp. bulgaricus TY30 (M1), Lb. acidophilus NRRL-B 1910, Lb. casei D4 and Lb. delbrueckii ssp. bulgaricus TY30 (M2), no bacterial inoculation as control $(C)$, chemically acidified dough (CAD). Some dough samples (LA, LC, M2, M1, C and

Table 1: Sourdough Formulations

\begin{tabular}{|c|c|c|c|c|c|}
\hline \multirow[b]{2}{*}{ Code } & \multirow[b]{2}{*}{ Wheat flour (g) } & \multirow[b]{2}{*}{ Water (ml) } & \multicolumn{3}{|c|}{ LAB Cell suspension (ml), $2 \times 10^{8} \mathrm{CFU} / 30 \mathrm{ml}$} \\
\hline & & & $\begin{array}{c}\text { Lb. acidophilus NRRL-B } \\
1910\end{array}$ & Lb. casei D4 & $\begin{array}{l}\text { Lb. delbrueckii ssp } \\
\text { bulgaricus TY30 }\end{array}$ \\
\hline LA & 200 & 70 & 30 & - & - \\
\hline LC & 200 & 70 & - & 30 & - \\
\hline LD & 200 & 70 & - & - & 30 \\
\hline M1 & 200 & 40 & - & 30 & 30 \\
\hline M2 & 200 & 10 & 30 & 30 & 30 \\
\hline C & 200 & 100 & - & - & - \\
\hline CAD & 200 & 100 & - & - & - \\
\hline
\end{tabular}

LA: Dough fermented with $L b$. acidophilus NRRL-B 1910, LC: Dough fermented with $L b$. casei D4, LD: Dough fermented with $L b$. delbrueckii ssp. bulgaricus TY30, M1: Dough fermented with $L b$. casei D4 and $L b$. delbrueckii ssp. bulgaricus TY30, M2: Dough fermented with $L b$. acidophilus NRRL-B 1910, Lb. casei D4 and $L b$. delbrueckii ssp. bulgaricus TY30, C: Dough contains no bacterial inoculation (Control), CAD: Chemically acidified dough. 
CAD) were incubated in a glass beaker covered with foil at $37^{\circ} \mathrm{C}$ for $48 \mathrm{~h}$. On the other hand, the dough inoculated only with $L b$. delbrueckii ssp. bulgaricus TY30 (LD) was fermented at $42^{\circ} \mathrm{C}$ for $48 \mathrm{~h}$. In order to investigate the differences between acidities developed by chemical acidification and $L A B$ inoculation, dough without $L A B$ inoculation was acidified with lactic and acetic acid $(4: 1, \mathrm{v} / \mathrm{v})$ to $\mathrm{pH} 4.22$ at $5.5 \mathrm{~h}$ after the beginning of the fermentation (CAD).

\subsection{Determination of Fermentation Parameters}

The progress in fermentation was followed by measuring $\mathrm{pH}$, TTA and LAB concentration of each sourdough sample.

The $\mathrm{pH}$ and TTA of sourdough samples were measured at $0,3,6,24$ and $48 \mathrm{~h}$ of fermentation. Sourdough sample $(10 \mathrm{~g})$ was taken and after addition of $90 \mathrm{~mL}$ of ultra pure water, homogenization was done by using a bar blender for $40 \mathrm{~s}$. The $\mathrm{pH}$ of this homogenate was measured via a $\mathrm{pH}$ meter with a glass electrode (Hanna Instruments, U.S.). TTA was determined by titration with standardized $0.1 \mathrm{~mol} / \mathrm{L}$ $\mathrm{NaOH}$ [36]. The amount $(\mathrm{mL})$ of $0.1 \mathrm{~mol} / \mathrm{L} \mathrm{NaOH}$ which was consumed during analysis was recorded.

The LAB concentrations of sourdough samples were enumerated at $0,3,6,24$ and $48 \mathrm{~h}$ of fermentation by suspending $10 \mathrm{~g}$ of sourdough sample in $90 \mathrm{~mL}$ of sterile deionized water and further homogenized (60 s). After preparing serial dilutions of homogenized samples, double layer pour plate technique with MRS agar (15 g agar/L MRS broth) was used. Plates were incubated for $48 \mathrm{~h}$ at 37 and $42^{\circ} \mathrm{C}$, the latter was for sample LD. Colonies on plates containing a range of 30-300 colonies were counted.

\subsection{Fractional Extraction of Wheat Proteins}

Wheat protein fractions were extracted sequentially from sourdough samples taken at 0,24 and $48 \mathrm{~h}$ of fermentation, according to Weiss et al. [37] which is the modified procedure of a method described by Osborne [38]. Gliadin extracts were stored at $-80^{\circ} \mathrm{C}$ until further analyses.

\subsection{Sodium Dodecyl Sulfate-Polyacrylamide Gel Electrophoresis (SDS-PAGE)}

SDS-PAGE was applied to gliadin extracts according to Laemmli system [39]. Polyacrylamide gel (12\% separating, $4 \%$ stacking) was poured between the glass plates (PROTEAN II XL system, Bio-Rad,
U.S.). The gliadin extracts were mixed with the sample buffer in a ratio of ca. 1:9 (v/v), according to nanodrop (NanoDrop 8000, Thermo Scientific) measurements and were heated in boiling water for $5 \mathrm{~min}$. After loading $10 \mu \mathrm{L} /$ well of each sample and $2 \mu \mathrm{L}$ of marker (\#SM0671, Fermentas, Canada) to the wells, the electrophoresis was carried out at a constant current of $32 \mathrm{~mA}$ for $30 \mathrm{~min}$ and $48 \mathrm{~mA}$ for $5 \mathrm{~h}$ at $10^{\circ} \mathrm{C}$. After the run was over, gel was taken out and kept in a fixer solution until silver staining.

\subsection{Two-Dimensional Electrophoresis (2-DE)}

Immobilized $\mathrm{pH}$ gradient (IPG) strips, nonlinear $\mathrm{pH}$ 3-10 and $17 \mathrm{~cm}$ (Bio-Rad 163- 2009, U.S.), were used in 2-DE. Gliadin extract, which contained $30 \mu \mathrm{g}$ of protein, was mixed with rehydration buffer. The strips were incubated with a total amount of $400 \mu$ of that sample mixture at room temperature for $1 \mathrm{~h}$ and rehydrated overnight at $25^{\circ} \mathrm{C}$. After rehydration, the IPG strips were placed onto the separating gel and isoelectric focusing (IEF) was carried out under stated focusing conditions [10] with some modifications (PROTEAN IEF cell, Bio-Rad, U.S.). Applied voltages and times were 0-300 V, $1 \mathrm{~h} ; 300-500 \mathrm{~V}$, 3h; 500-2000 $\mathrm{V}, 4 \mathrm{~h} ; 2000-8000 \mathrm{~V}, 32000 \mathrm{~V}-\mathrm{h}$ and $8000-500 \mathrm{~V}$ until the end, at $20^{\circ} \mathrm{C}$. After that step, $6 \mathrm{~mL}$ of equilibration buffer I [ $6 \mathrm{~mol} / \mathrm{L}$ urea, $2 \%$ SDS (w/v), $0.375 \mathrm{~mol} / \mathrm{L}$ Tris$\mathrm{HCl}(\mathrm{pH} 8.8), 20 \%$ glycerol (v/v), $130 \mathrm{~mol} / \mathrm{m}^{3}$ 1,4-DithioDL-threit(ol) (DTT)] was added for one strip and shaked (40 r. $\mathrm{min}^{-1}, 10 \mathrm{~min}$ ). Equilibration buffer I was removed and $6 \mathrm{~mL}$ of equilibration buffer II [6 mol/L urea, $2 \%$ SDS (w/v), $0.375 \mathrm{~mol} / \mathrm{L}$ Tris- $\mathrm{HCl}$ (pH 8.8), $20 \%$ glycerol $(\mathrm{v} / \mathrm{v}), 135 \mathrm{~mol} / \mathrm{m}^{3}$ iodoacetamide (freshly added)] was added onto each strip and shaked (40 r.min ${ }^{-1}, 10 \mathrm{~min}$ ).

For the second dimension, the separating gel was cast and the low-melt overlay agarose was pipetted to the space above the gel. The equilibrated IPG strip was placed onto the SDS gel. Electrophoresis was carried out at a constant current of $48 \mathrm{~mA}$ for $5.5 \mathrm{~h}$ at $10^{\circ} \mathrm{C}$. Gel was put into a fixer solution until silver staining. Same procedures were also applied to 2-D SDS-PAGE Standard (Bio-Rad 161-0320, U.S.).

\subsection{Silver Staining of SDS-PAGE and 2-D Gels and Monitoring}

Gel was washed with $50 \%$ ethanol three times for 20 min each and then kept in pretreatment solution $(0.02 \%$ sodium thiosulfate, $w / v)$ for $1 \mathrm{~min}$. It was rinsed with ultra pure water three times for $20 \mathrm{~s}$ each and was further treated with silver nitrate solution $[0.2 \%$ silver 
nitrate (w/v), $0.0375 \%$ formaldehyde $(\mathrm{v} / \mathrm{v})$ ] for $20 \mathrm{~min}$. Again, it was washed with ultra pure water twice for 20 $\mathrm{s}$ each until color development. Gel was placed in a developing solution $[2.25 \%$ potassium carbonate $(\mathrm{w} / \mathrm{v})$, $0.0004 \%$ sodium thiosulfate (w/v), $0.075 \%$ formaldehyde $(\mathrm{v} / \mathrm{v})]$. After a few minutes, some ultra pure water was added to slow down the reaction. When gliadins appeared in a satisfactory extend, ultra pure water was added and gel was rinsed twice, 2 min each. Finally, stop solution [ $50 \%$ methanol $(\mathrm{v} / \mathrm{v}), 12 \%$ acetic acid $(\mathrm{v} / \mathrm{v})$ ] was applied and gels were kept in this solution until monitoring. Orbital shaker was utilized during the whole staining procedure. The silver stained gels were monitored by using an imaging system (VersaDoc 4000 MP, Bio-Rad, U.S.). Molecular weights and pls of gliadins were calculated by using Quantity One 1-D Analysis Software and Bio 2-D Software (BioRad, U.S.), respectively.

\subsection{Reverse Phase-High Performance Liquid Chromatography (RP-HPLC)}

RP-HPLC analysis of gliadins was done as stated in a previous study [40]. Fifteen $\mu \mathrm{L}$ of filtered $(0.45 \mu \mathrm{m})$ gliadin extract was injected to $5 \mu \mathrm{m}, 15 \mathrm{~cm} \times 4.6 \mathrm{~mm}$ Zorbax SB300-C18 Reverse-Phase column (Agilent Technologies, U.S.) and analyzed for 120 min using a linear acetonitrile $(0.1 \%$ trifluoroacetic acid, $\mathrm{v} / \mathrm{v})$ gradient from 24 to $50 \%$ over 108 min (Perkin Elmer Series 200, USA). Column temperature was $60^{\circ} \mathrm{C}$ and $210 \mathrm{~nm}$ was used to monitor column effluent.

\subsection{Statistical Analysis}

Statistical evaluation of the data was conducted by MINITAB 14 software (Minitab Inc.,U.S.). Analysis of variance (ANOVA) and Tukey's test were used to investigate whether there was a significant difference in means $(p<0.05)$. Each analysis was performed in duplicate

\section{RESULTS AND DISCUSSIONS}

\subsection{Flour Characteristics}

According to the results of proximate composition analysis, wheat flour had protein content of $10.78 \pm$ $0.14 \mathrm{~g} / 100 \mathrm{~g}$ dry matter (DM), moisture level of $11.48 \pm$ $0.09 \mathrm{~g} / 100 \mathrm{~g}$ and ash content of $0.54 \pm 0.008 \mathrm{~g} / 100 \mathrm{~g}$ DM (type 550). The wheat flour used in preparation of sourdoughs complied with standards [41] and by these results, it was validated that sourdough fermentation was performed by using a standard wheat flour.

\subsection{Changes in pH, TTA, LAB Count}

Adaptation of $L A B$ to wheat sourdough environment was followed by the changes in the $\mathrm{pH}$, TTA and $\mathrm{LAB}$ inoculum concentrations. During the whole sourdough fermentation process, there was a significant decrease in the $\mathrm{pH}$ values of all samples $(\mathrm{p}<0.05)$ (Figure 1a). Also, a significant difference was observed between the $\mathrm{pH}$ values of sourdough samples at certain fermentation times $(p<0.05)$. The decrease in $\mathrm{pH}$ from ca. 6.1 to ca. 3.7 was recorded in $48 \mathrm{~h}$ of fermentation period. In all $L A B$ inoculated doughs, final $\mathrm{pH}$ varies within the range of 3.47-3.80. At $24 \mathrm{~h}$, all inoculated doughs, except sample LD, reached the values similar to those at $48 \mathrm{~h}$. A slight $\mathrm{pH}$ drop to 4.55 at $24 \mathrm{~h}$ was recorded in the case of LD due to the low growth rate of the strain used. The $\mathrm{pH}$ decrease was faster in samples LA, LC, M1 and M2 which contained $L b$. acidophilus NRRL-B 1910 and/or Lb. casei D4. In control dough, the $\mathrm{pH}$ values at $24 \mathrm{~h}$ and $48 \mathrm{~h}$ of fermentation were 4.77 and 3.95, respectively. During the period after chemical acidification, only a small change was observed in the $\mathrm{pH}$ of CAD. It is important to mention that although there was a $\mathrm{pH}$ drop in both control and $L A B$ inoculated doughs, this reduction was lower than the inoculated doughs, particularly LA, LC, $\mathrm{M} 1$ and $\mathrm{M} 2$, at $24 \mathrm{~h}$. But at $48 \mathrm{~h}$, while there was not a significant drop $(p<0.05)$ in LA, LC, M1 and M2, the $\mathrm{pH}$ of control dough decreased to the level similar to other dough samples. These results showed that the $\mathrm{pH}$ decrease in control dough was due to its own natural microflora. On the other hand, the $\mathrm{pH}$ of CAD remained almost at the same level between 6 and $24 \mathrm{~h}$. It is likely that the reduction of $\mathrm{pH}$ by the acid addition inhibited the natural growth of bacteria in wheat flour microflora. In a previous research, final $\mathrm{pH}$ of sourdough samples were found as between the values of 3.90 to 3.70 [11]. In another literature, in which probiotic preparations were used in sourdough fermentation, the $\mathrm{pH}$ was reached to 3.7 to 4.0 after $24 \mathrm{~h}$ [13]. According to a different study, it was observed that fermented doughs had the $\mathrm{pH}$ decrease from ca. 6.5 to $4.5-5.0$ after $8 \mathrm{~h}$ and the $\mathrm{pH}$ was in the range of 3.5-4.0 at the end of 24 $h$ [42]. In another study of the same research group samples, which were taken at 6 and $24 \mathrm{~h}$, had $\mathrm{pH}$ values of 4.5-5.5 and 3.6-3.8, respectively [43].

Changes in TTA values of all samples during $48 \mathrm{~h}$ of fermentation were significant $(p<0.05)$ and were in agreement with $\mathrm{pH}$ changes. Additionally, a significant difference was observed between the TTA values of sourdough samples at certain fermentation times $(p<0.05)$. The TTA values of all LAB inoculated 
doughs, which were between 1.75-1.85 range initially, reached to 3.94-14.40 and 11.45-15.70 range after 24 and $48 \mathrm{~h}$ of fermentations, respectively (Figure 1b). In a previous study, it was found that a rye sourdough fermentation reached a TTA value of $17 \pm 2.5$ at the end of $24 \mathrm{~h}$ fermentation [44].

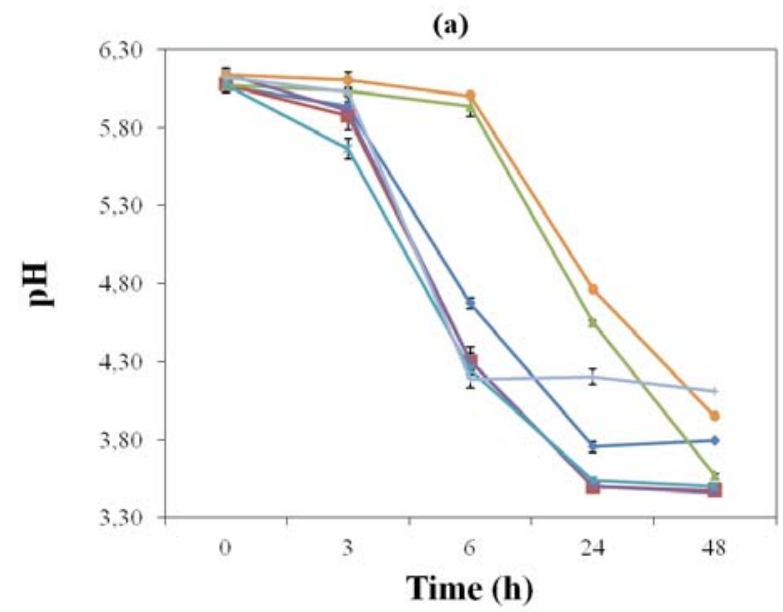

(b)

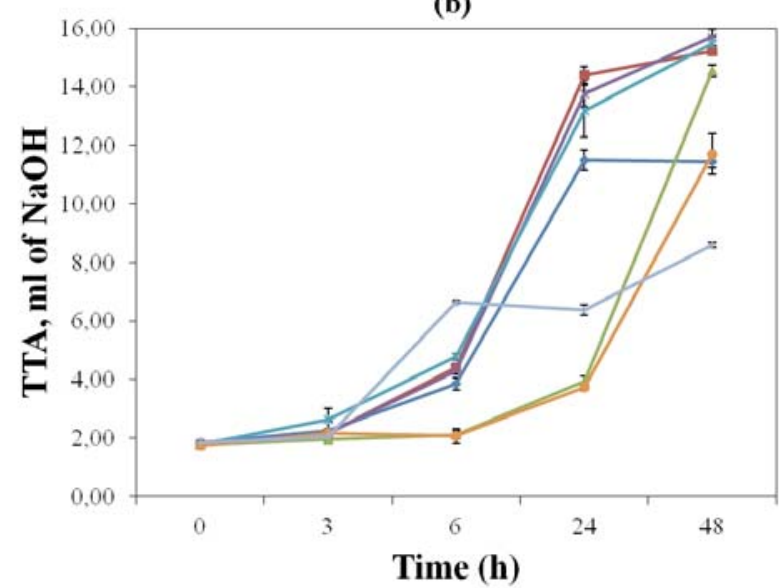

(c)

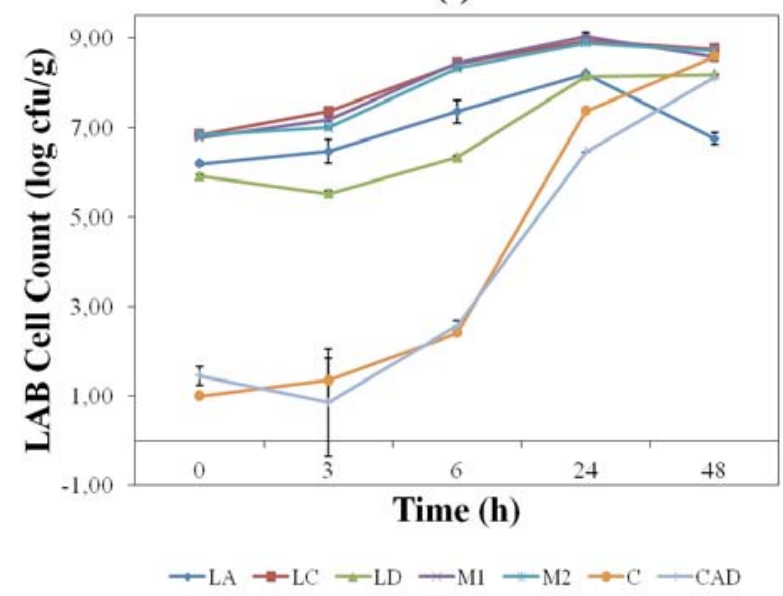

Figure 1: Changes in (a) $\mathrm{pH}$, (b) TTA and (c) LAB counts (log CFU/g) of sourdough samples during fermentation.
In all samples, during $48 \mathrm{~h}$ of fermentation, changes in LAB concentrations were found significant $(p<0.05)$ and also a significant difference was observed between the LAB counts of sourdough samples at certain fermentation times $(p<0.05)$. The $L A B$ population of inoculated doughs was counted as ca. $1.62 \times 10^{8}$. $1.09 \times 10^{9} \mathrm{CFU} / \mathrm{g}$ dough at the end of $24 \mathrm{~h}$ of fermentation (Figure 1c). After $24 \mathrm{~h}$, LAB population of samples started to decrease except the one in the sample LD. The enumeration results of control and CAD showed that a LAB growth, which constituted the microflora of wheat flour, occured and the concentrations reached to $2.7 \times 10^{3}, 3.2 \times 10^{7}$ and $3.8 \times 10^{8}$ CFU/g for control sample and to $1.0 \times 10^{2}, 1.4 \times 10^{6}$ and $3.2 \times 10^{7}$ for $C A D$ at 6,24 and $48 \mathrm{~h}$, respectively. In previous studies in the related literature, the $L A B$ content of sourdoughs at the end of 24 and $48 \mathrm{~h}$ were found as ca. $10^{9} \mathrm{CFU} / \mathrm{g}$ sourdough $[10,11]$.

\subsection{SDS-PAGE Profiles of Gliadin Extracts}

The SDS-PAGE results of gliadins extracted from samples which were taken at the beginning $(0 \mathrm{~h})$ of sourdough fermentation shows that gliadin bands were located in the $42-29 \mathrm{kDa}$ range (Figure 2). Previous studies and literature findings have indicated that gliadins are divided into three groups according to their mobilities in SDS-PAGE gel as $\omega$-gliadins $(50,000$ 75,000), $\quad \gamma$-gliadins and $\alpha / \beta$-gliadins ( $M_{r} s \quad 30,000$ $45,000)[45,38]$. According to this information, it can be said that our gliadin extracts contain $\gamma$-gliadins and $\alpha / \beta$ gliadins. The absence of $\omega$-gliadins could be due to the extraction procedure used in this study. The SDSPAGE gel also contains bands which have lower $M_{r} s$ such as $21,000-10,000$. This is because of the occurrence polymers related to the glutenins in the alcohol-extractable gliadin fraction. They differ from the alcohol-unextractable glutenins in having lower molecular weights and higher contents of low molecular weight (LMW) subunits. They are called as "aggregated gliadins" or "LMW glutenin" [46].

In all gliadins, which were extracted from inoculated sourdough samples taken at $0 \mathrm{~h}$ of fermentation, the bands at 38 and $37 \mathrm{kDa}$ existed (Figure 2). With the progress of fermentation, changes occurred in the protein structure and these two bands disappeared $(A)$. When different sample bands were compared at $24 \mathrm{~h}$, except for the sample LD, bands with molecular weights of 38,37 and $28 \mathrm{kDa}(\mathrm{A}$ and $\mathrm{B})$ disappeared. On the other hand, four new bands with molecular weights in the range of $27-25 \mathrm{kDa}$ formed (C). The same changes occured in sample LD, more slowly (48 


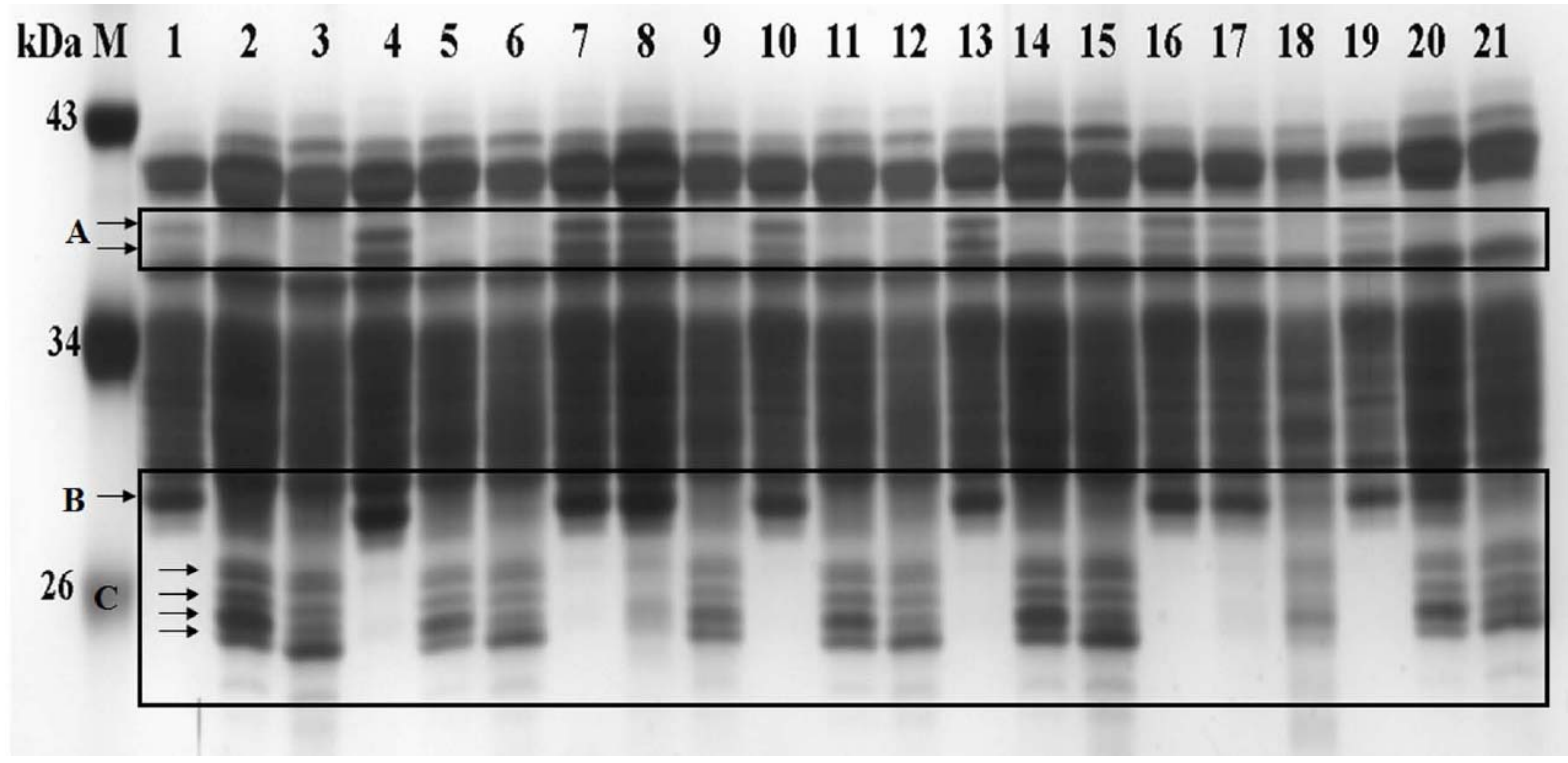

Figure 2: SDS-PAGE gel (12\%) of gliadin fractions from sourdough samples. M represents the molecular weight marker; Lanes 1, 2, 3 correspond to sample LA at 0,24 and $48 \mathrm{~h}$; Lanes 4, 5, 6 correspond to sample LC at 0, 24 and 48 h; Lanes 7, 8, 9 correspond to sample LD at 0, 24 and $48 \mathrm{~h}$; Lanes 10,11, 12 correspond to sample M2 at 0, 24 and 48 h; Lanes 13, 14,15 correspond to sample M1 at 0, 24 and 48 h; Lanes 16, 17, 18 correspond to sample C at 0, 24 and 48 h; Lanes 19, 20 , 21 correspond to sample CAD at 0,24 and $48 \mathrm{~h}$.

h). In control dough, the same changes occurred as in the LD, but only two new bands formed (27 and 25 $\mathrm{kDa}$ ) instead of four bands. CAD had also the same band appearance as the inoculated doughs. Although time for fermentation differs, these changes occurred during sourdough fermentation in all samples and also in chemically acidified and control doughs. Because of this reason, the gliadin band modification could be attributed to protein degradation which is not specific to any bacterial species used. Wheat flour enzymes such as aspartic proteinases and serine carboxypeptidases which are active at acidic $\mathrm{pH}$ ranges, 3.0-4.5 and 4.06.0 , respectively, are likely to be responsible for the degradation $[7,9,47]$.

\subsection{2-DE of Gliadin Extracts}

The 2-D gel images of gliadins extracted from sample LC at $0 \mathrm{~h}$ and $24 \mathrm{~h}, \mathrm{M} 1$ at $24 \mathrm{~h}$ and LD at $48 \mathrm{~h}$ are shown in Figure 3. On 2-D gels of gliadin extracts of samples taken at the beginning of fermentation $(0 \mathrm{~h})$ 51 spots were detected. In agreement with previous studies [38] in which the location of gliadins stated as $35-50 \mathrm{kDa}$ and $\mathrm{pl}$ from 6.5 to 9 , the gliadin spots located mostly in 30-42 kDa range and at pl 5.7-9.8. After $24 \mathrm{~h}$ of fermentation two spots (spots 1 and 2) with molecular weight of ca. $39 \mathrm{kDa}$ and $\mathrm{pl}$ of 6.4 and 6.7 and one spot (spot 3) with molecular weight of ca. $38 \mathrm{kDa}$ and $\mathrm{pl}$ of 7.1 were disappeared. Also newly formed very small spots were observed in a wide region (region 4 ) which were particularly located in the ranges of ca. $30-29 \mathrm{kDa}$ and $\mathrm{pl}$ of 6.5-8.9 and ca. 28$27 \mathrm{kDa}$ and $\mathrm{pl}$ of 8.9-9.5. Obtained results from 2-DE showed similarity with SDS-PAGE findings but it gives more detailed representation of the locations of the gliadins. The spot disappearance and formation occurred after $24 \mathrm{~h}$ in LA, LC, M1, M2 and CAD, and after $48 \mathrm{~h}$ in control and LD. Changes occurred in all samples and also in chemically acidified and control doughs. The results seemed to indicate that there was a positive correlation between gliadin degradation and acidity development. The disappearance and formation of the spots were due to the effect of acidification (CAD) and acidity development by LAB inoculation. $\mathrm{LAB}$ gradually shifted the $\mathrm{pH}$ to ca. 3.5-4.0 and during this period wheat flour proteolytic enzymes reached their optimum $\mathrm{pH}$ values. Activated enzymes catalyzed the breakdown of proteins to peptides. Since no different spot alteration occurred in CAD, protein degradation might not be specific to any bacterial species used.

\subsection{RP-HPLC}

Since similar changes were observed in all chromatograms, only the representative chromatograms of gliadin extracts of sample LC $(0,24$ and $48 \mathrm{~h})$ were given in Figure 4. In all dough samples, the peak appearance of gliadin fractions underwent some significant changes, which occurred due to the structural changes of proteins, as fermentation progressed. The main alterations in chromatograms of 


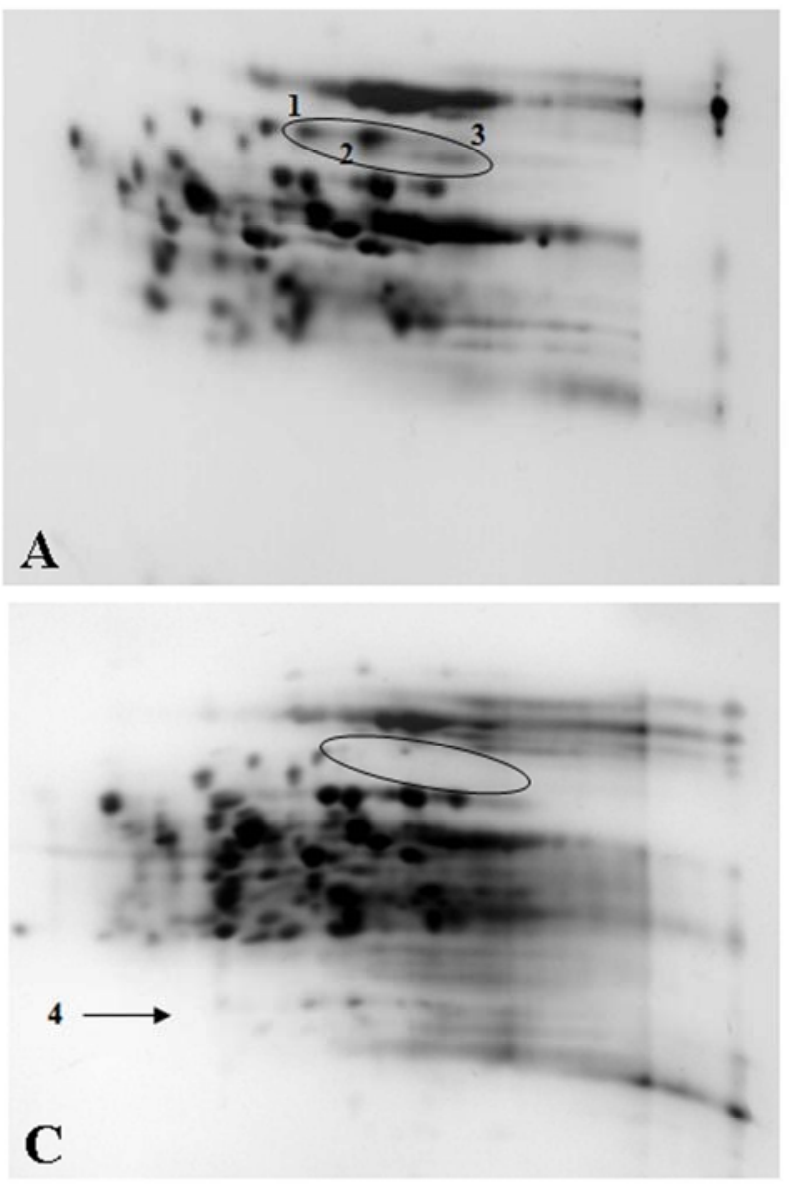

Figure 3: Enlarged views of 2-D gels of gliadin extracts from (A)

samples LA, LC, M1 and M2 were observed after $24 \mathrm{~h}$ and $48 \mathrm{~h}$ of fermentations. The peaks 3 (Retention time, $\left.\mathrm{R}_{\mathrm{t}}=83.58\right)$ and $4\left(\mathrm{R}_{\mathrm{t}}=85.45\right)$ disappeared, also peaks $5 \quad\left(R_{t}=91.45\right)$ and $6 \quad\left(R_{t}=94.22\right)$ lost their intensities after $24 \mathrm{~h}$. Samples LA, LC, M1 and M2 further had additional changes such as the disappearance of peaks $1\left(\mathrm{R}_{\mathrm{t}}=66.26\right), 2\left(\mathrm{R}_{\mathrm{t}}=77.16\right.$ and 77.92), 5 and 6 at $48 \mathrm{~h}$. In control dough, CAD and LD no distinctive changes were investigated after $24 \mathrm{~h}$. At the end of $48 \mathrm{~h}$ of fermentation, the peaks 3 and 4 disappeared, also peaks 1, 2, 5 and 6 lost their intensities. These results were in accordance with SDS-PAGE and 2-DE results. While no differences in bands and/or spots were observed in gel for LC at 24 and $48 \mathrm{~h}$ in electrophoresis gels, the disappearance of peaks 2,5 and 6 could be observed in RP-HPLC chromatograms. So it is possible to conclude that RPHPLC was more versatile than electrophoretic methods.

\section{CONCLUSION}

A group of $L A B$ isolated from dairy products were examined for their gliadin degradation ability into a non-
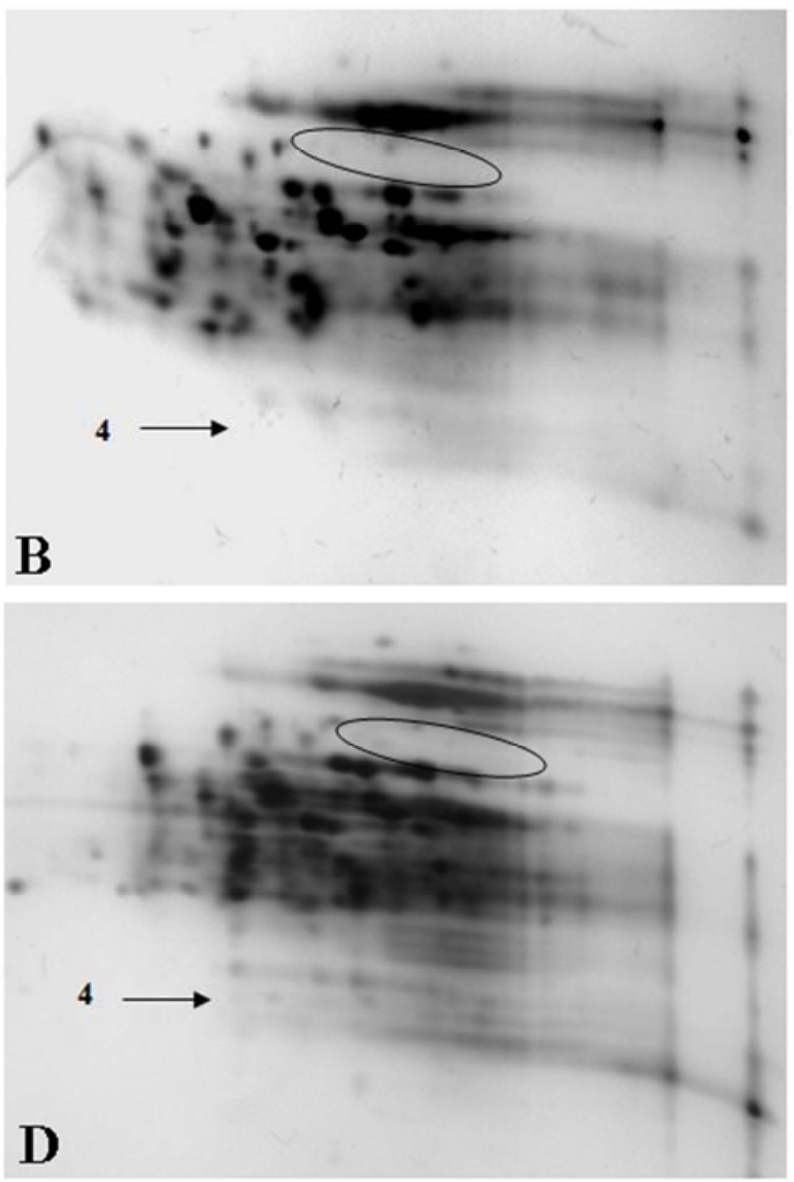

D

dairy medium. The decrease in $\mathrm{pH}$ and the increase in total acidity were recorded. Characterization of protein profiles obtained from SDS-PAGE, 2-DE and RP-HPLC techniques provided information on molecular weight and $\mathrm{pl}$ of gliadin fractions degraded. The degradation capability of sourdoughs with "LAB inoculation" and "chemical acidification" were found to be superior to "non inoculated \& not acidified" (control) dough samples in variation with $\mathrm{pH}$. The results seemed to indicate that $L A B$ contribute to this degradation with the developing acidity and proteolytic activity which enhance the breakdown of proteins. Activation of endogenous proteolytic enzymes of wheat flour also contributes to this process in high acidic environments. In addition to $L b$. casei and $L b$. acidophilus, their mixed culture combinations have also been identified for higher adaptation and gliadin degradation capability in wheat-based medium. This study has been based on a M.Sc. thesis [48] and it has basically dealt with the structural changes of gliadin in wheat dough. Studies on bread making with culture combinations including high exopolysaccharide producer $L b$. delbrueckii ssp. bulgaricus together with $L b$. casei are underway and will be the context of the next publication 


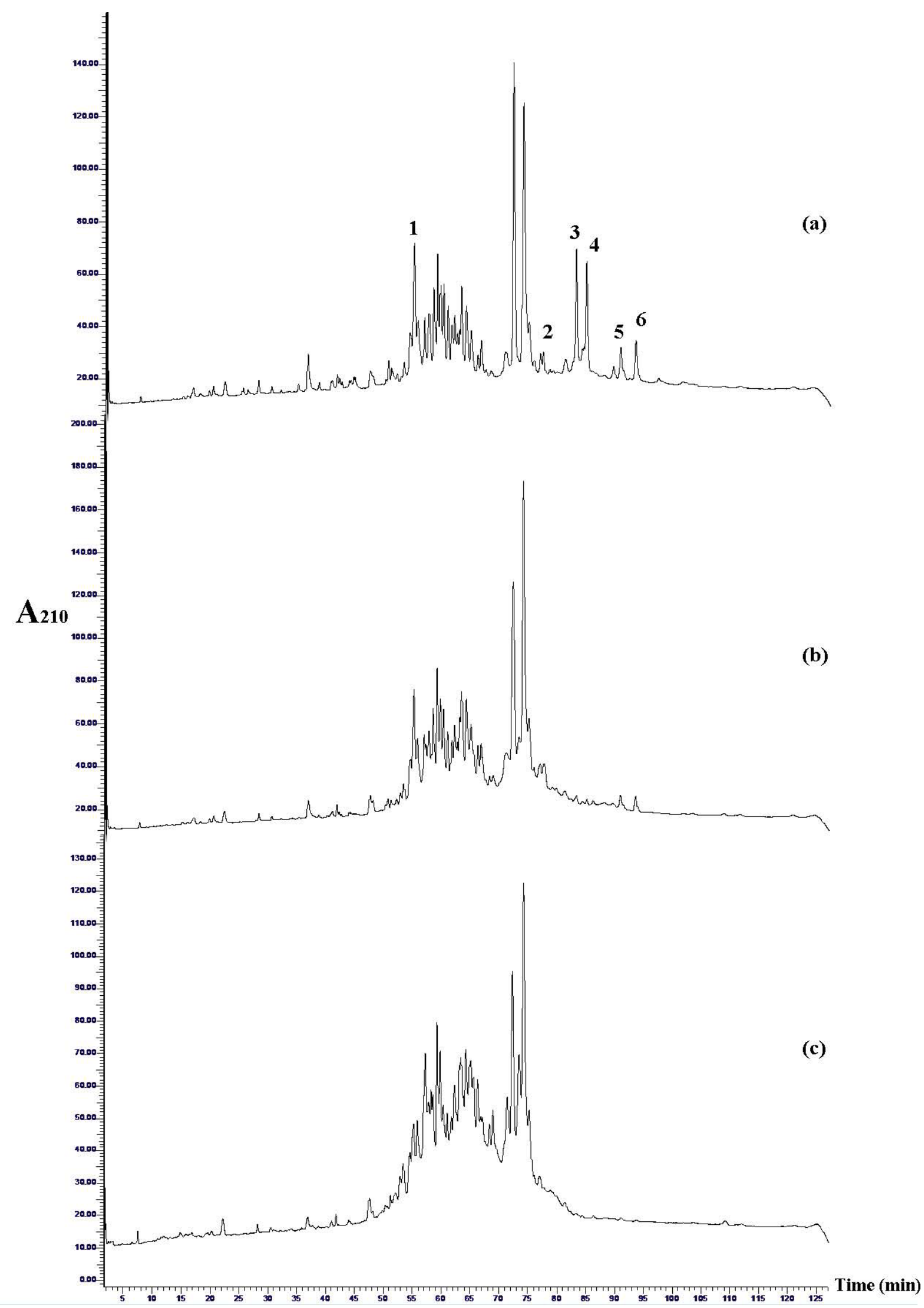

Figure 4: RP-HPLC chromatograms of sample LC at fermentation times of (a) $0 \mathrm{~h}$ (b) $24 \mathrm{~h}$ (c) $48 \mathrm{~h}$.

elsewhere. In the case of naturally gluten-free raw materials and incorporation into bread formulations, and utilization of above strains in related sourdough fermentations should be evaluated both for 
contaminating gluten removal and improving their quality further.

\section{ACKNOWLEDGEMENTS}

We would like to acknowledge Biotechnology and Bioengineering Application and Research Center of Izmir Institute of Technology for the laboratory facilities. We thank Mert Sudagidan for his assistance during SDS-PAGE and 2-DE analyses.

\section{ABBREVIATIONS}

$\begin{array}{ll}2-\mathrm{DE} & =\text { Two-dimensional electrophoresis } \\ \mathrm{CAD} & =\text { Chemically acidified dough } \\ \mathrm{CFU} & =\text { Colony forming unit } \\ \text { IEF } & =\text { Isoelectric Focusing } \\ \text { IPG } & =\text { Immobilized pH gradient } \\ \text { LAB } & =\text { Lactic acid bacteria } \\ \text { Mr } & =\text { Relative molecular mass } \\ \text { MRS } & =\text { de Man, Rogosa and Sharpes } \\ \text { pl } & =\text { Isoelectric point }\end{array}$

RP-HPLC = Reverse phase-high performance liquid chromatography

Rt $\quad=$ Retention time

SDS-PAGE = Sodium dodecyl sulfatepolyacrylamide gel electrophoresis

TTA $=$ Total titratable acidity

\section{REFERENCES}

[1] Wieser H. Chemistry of gluten proteins. Food Microbiol 2007; 24(2): 115-9. http://dx.doi.org/10.1016/j.fm.2006.07.004

[2] Lindfors $\mathrm{K}$, Blomqvist $\mathrm{T}$, Juuti-Uusitalo $\mathrm{K}$, Stenman $\mathrm{S}$, Venäläinen $\mathrm{J}$, Mäki $\mathrm{M}$, et al. Live probiotic Bifidobacterium lactis bacteria inhibit the toxic effects induced by wheat gliadin in epithelial cell culture. Clin Exp Immunol 2008; 152(3): 552-8.

http://dx.doi.org/10.1111/i.1365-2249.2008.03635.x

[3] Stepniak D, Spaenij-Dekking L, Mitea C, Moester M, de Ru A, Baak-Pablo $R$, et al. Highly efficient gluten degradation with a newly identified prolyl endoprotease: Implications for celiac disease. Am J Physiol Gastrointest Liver Physiol 2006; 291(4): G621-9.

http://dx.doi.org/10.1152/ajpgi.00034.2006

[4] Mearin ML. Celiac disease among children and adolescents. Curr Probl Pediatr Adolesc Health Care 2007; 37(3): 86-105. http://dx.doi.org/10.1016/j.cppeds.2007.01.001
Fasano A, Catassi C. Current approaches to diagnosis and treatment of celiac disease: An evolving spectrum. Gastroenterology 2001; 120: 636-51. http://dx.doi.org/10.1053/gast.2001.22123

[6] Gänzle MG. Enzymatic and bacterial conversions during sourdough fermentation. Food Microbiol. Forthcoming 2013. http://dx.doi.org/10.1016/j.fm.2013.04.007

[7] Bleukx W, Reels SP, Delcour JA. On the presence and activities of proteolytic enzymes in vital wheat gluten. $\mathrm{J}$ Cereal Sci 1997; 26: 183-93.

http://dx.doi.org/10.1006/jcrs.1997.0123

[8] Bleukx W, Torrekens S, Van Leuven F, Delcour JA Purification, properties and $\mathrm{N}$-terminal amino acid sequence of a wheat gluten aspartic proteinase. J Cereal Sci 1998; 28: 223-32. http://dx.doi.org/10.1016/S0733-5210(98)90002-9

[9] Bleukx W, Brijs K, Torrekens S, Van Leuven F, Delcour JA. Specifity of a wheat gluten aspartic proteinase. Biochim Biophys Acta 1998; 1387: 317-24.

http://dx.doi.org/10.1016/S0167-4838(98)00146-0

[10] Di Cagno R, De Angelis M, Lavermicocca P, De Vincenzi M, Giovannini C, Faccia M, Gobbetti M. Proteolysis by sourdough lactic acid bacteria: Effects on wheat flour protein fractions and gliadin peptides involved in human cereal intolerance. Appl Environ Microbiol 2002; 68(2): 623-33. http://dx.doi.org/10.1128/AEM.68.2.623-633.2002

[11] Di Cagno R, De Angelis M, Auricchio S, Grecu L, Clarke C, De Vincenzi M, et al. Sourdough bread made from wheat and nontoxic flours and started with selected lactobacilli is tolerated in celiac sprue patients. Appl Environ Microbiol 2004; 70(2): 1088-96. http://dx.doi.org/10.1128/AEM.70.2.1088-1096.2004

[12] Tuukkanen K, Loponen J, Mikola M, Sontag-Strohm T, Salovaara H. Degradation of secalins during rye sourdough fermentation. Cereal Chem 2005; 82(6): 677-82. http://dx.doi.org/10.1094/CC-82-0677

[13] De Angelis M, Rizzello CG, Fasano A, Clemente MG, De Simone C, Silano M, et al. VSL\#3 probiotic preparation has the capacity to hydrolyze gliadin polypeptides responsible for Celiac Sprue. Biochim Biophys Acta 2006; 1762(1): 80-93. http://dx.doi.org/10.1016/j.bbadis.2005.09.008

[14] Rizzello CG, De Angelis M, Di Cagno R, Camarca A, Silano $M$, Losito $I$, et al. Highly efficient gluten degradation by lactobacilli and fungal proteases during food processing: New perspectives for celiac disease. Appl Environ Microbiol 2007; 73(14): 4499-507.

http://dx.doi.org/10.1128/AEM.00260-07

[15] Gänzle MG, Loponen J, Gobbetti M. Proteolysis in sourdough fermentations: Mechanisms and potential for improved bread quality. Trends Food Sci Technol 2008; 19(10): 513-21.

http://dx.doi.org/10.1016/j.tifs.2008.04.002

[16] Arendt EK, Ryan LAM, Dal Bello F. Impact of sourdough on the texture of bread. Food Microbiol 2007; 24: 165-74. http://dx.doi.org/10.1016/j.fm.2006.07.011

[17] Poutanen K, Flander L, Katina K. Sourdough and cereal fermentation in a nutritional perspective. Food Microbiol 2009; 26: 693-9.

http://dx.doi.org/10.1016/j.fm.2009.07.011

[18] Hansen A, Schieberle P. Generation of aroma compounds during sourdough fermentation: Applied and fundamenta aspects. Trends Food Sci Technol 2005; 16: 85-94. http://dx.doi.org/10.1016/j.tifs.2004.03.007

[19] Ganzle MG, Vogel RF. Contribution of reutericyclin production to the stable persistence of Lactobacillus reuteri in an industrial sourdough fermentation. Int $\mathrm{J}$ Food Microbiol 2003; 80(1): 31-45.

http://dx.doi.org/10.1016/S0168-1605(02)00146-0 
[20] Welman AD, Maddox IS. Exopolysaccharides from lactic acid bacteria: Perspectives and challenges. Trends Biotechnol 2003; 21(6): 269-74. http://dx.doi.org/10.1016/S0167-7799(03)00107-0

[21] Di Cagno R, De Angelis M, Limitone A, Minervini F, Carnevali $\mathrm{P}$, Corsetti $\mathrm{A}$, et al. Glucan and fructan production by sourdough Weissella cibaria and Lactobacillus plantarum. J Agric Food Chem 2006; 54: 9873-81. http://dx.doi.org/10.1021/jf061393

[22] Katina K, Maina NH, Juvonen R, Flander L, Johansson L, Virkki L, et al. In situ production and analysis of Weissella confusa dextran in wheat sourdough. Food Microbiol 2009; 26: 734-43.

http://dx.doi.org/10.1016/j.fm.2009.07.008

[23] Lacaze G, Wick M, Cappelle S. Emerging fermentation technologies: Development of novel sourdoughs. Food Microbiol 2007; 24: 155-60. http://dx.doi.org/10.1016/j.fm.2006.07.015

[24] Tieking M, Gänzle MG. Exopolysaccharides from cereal associated lactobacilli. Trends Food Sci Technol 2005; 16: 79-84.

http://dx.doi.org/10.1016/j.tifs.2004.02.015

[25] Abraham AG, De Antoni GL, Añon MC. Proteolytic activity of Lactobacillus bulgaricus grown in milk. J Dairy Sci 1993; 76(6): 1498-505. http://dx.doi.org/10.3168/jds.S0022-0302(93)77481-0

[26] González L, Sacristán N, Arenas R, Fresno JM, Tornadijo ME. Enzymatic activity of lactic acid bacteria (with antimicrobial properties) isolated from a traditional Spanish cheese. Food Microbiol 2010; 27(5): 592-7. http://dx.doi.org/10.1016/j.fm.2010.01.004

[27] Plessas S, Alexopoulos A, Mantzourani I, Koutinas A, Voidarou C, Stavropoulou E, et al. Application of novel starter cultures for sourdough bread production. Anaerobe 2011; 17: 486-9.

http://dx.doi.org/10.1016/j.anaerobe.2011.03.022

[28] Plessas S, Fisher A, Koureta K, Psarianos C, Nigam P, Koutinas AA. Application of Kluyveromyces marxianus, Lactobacillus delbrueckii ssp. bulgaricus and L. helveticus for sourdough bread making. Food Chem 2008; 106: 985-90. http://dx.doi.org/10.1016/..foodchem.2007.07.012

[29] Plessas S, Pherson L, Bekatorou A, Nigam P, Koutinas AA. Bread making using kefir grains as baker's yeast. Food Chem 2005; 93: 585-9.

http://dx.doi.org/10.1016/j.foodchem.2004.10.034

[30] Bulut C. Isolation and molecular characterization of lactic acid bacteria from cheese [Master Thesis]. Izmir: Izmir Institute of Technology 2003.

[31] Çelik, ES. Determination of aroma compounds and exopolysaccharides formation by lactic acid bacteria isolated from traditional yogurts [Master Thesis]. Izmir: Izmir Institute of Technology 2007.

[32] Erkus O. Isolation, phenotypic and genotypic characterization of yoghurt starter bacteria [Master Thesis]. Izmir: Izmir Institute of Technology 2007.

[33] AACC. Crude protein- Kjeldahl method, boric acid modification. $11^{\text {th }}$ Edition. AACC International, St. Paul, MN, USA; 1999. 3 p. Method No.: 46-16.01.

http://dx.doi.org/10.1094/AACCIntMethod-46-16.01
[34] ICC. Determination of the moisture content of cereals and cereal products (Practical method). Vienna, Austria; 1976. Standard No.: 110/1.

[35] ICC. Determination of ash in cereals and cereal products. Vienna, Austria; 1990. Standard No.: 104/1.

[36] Cemeroğlu B, Eds. Gıda analizlerinde genel yöntemler, gıda analizleri. Ankara: Bizim Grup Basımevi 2010.

[37] Weiss W, Vogelmeier C, Görg A. Electrophoretic characterization of wheat grain allergens from different cultivars involved in bakers' asthma. Electrophoresis 1993; 14(1): 805-16.

http://dx.doi.org/10.1002/elps.11501401126

[38] Osborne TB. The protein of the wheat kernel. Washington: Carnegie Institute 1907.

[39] Laemmli UK. Cleavage of structural proteins during the assembly of the head of bacteriophage T4. Nature 1970; 227(5259): 680-5. http://dx.doi.org/10.1038/227680a0

[40] Qian Y, Preston K, Krokhin O, Mellish J, Ens W. Characterization of wheat gluten proteins by HPLC and MALDI TOF mass spectrometry. J Am Soc Mass Spectrom 2008; 19(10): 1542-50. http://dx.doi.org/10.1016/j.jasms.2008.06.008

[41] Codex Alimentarius Commission. Codex standard for wheat flour. USA; 1995. 3 p. Standard No.: 152-1985. Available from: http://www.codexalimentarius.org/standards

[42] Thiele C, Gänzle MG, Vogel RF. Contribution of sourdough lactobacilli, yeast, and cereal enzymes to the generation of amino acids in dough relevant for bread flavor. Cereal Chem 2002; 79(1): 45-51.

http://dx.doi.org/10.1094/CCHEM.2002.79.1.45

[43] Thiele C, Grassl S, Gänzle M. Gluten hydrolysis and depolymerization during sourdough fermentation. J Agric Food Chem 2004; 52(5): 1307-14. http://dx.doi.org/10.1021/jf034470z

[44] Loponen J, Kanerva P, Zhang C, Gänzle MG. Prolamin hydrolysis and pentosan solubilization in germinated-rye sourdoughs determined by chromatographic and immunological methods. J Agric Food Chem 2009; 57(2): 746-53.

http://dx.doi.org/10.1021/jf803243w

[45] Lindsay MP, Skerritt JH. The glutenin macropolymer of wheat flour doughs: structure-function perspectives. Trends Food Sci Technol 1999; 10(8): 247-53. http://dx.doi.org/10.1016/S0924-2244(00)00004-2

[46] Shewry PR, Tatham AS. Disulphide bonds in wheat gluten proteins. J Cereal Sci 1997; 25(3): 207-27. http://dx.doi.org/10.1006/jcrs.1996.0100

[47] Loponen J. Prolamin degradation in sourdoughs [Dissertation]. Helsinki: University of Helsinki; 2006 [cited 2012 Jan 8]. Available from: http://urn.fi/URN:ISBN:952-103582-X

[48] Komen G. Structural changes of gliadins during sourdough fermentation as a promising approach to gluten-free diet [Master Thesis]. Izmir: Izmir Institute of Technology 2010. 